DOI: $10.18276 / \operatorname{sip} .2017 .49 / 2-08$

\title{
Krystyna Żolądkiewicz
}

Uniwersytet Gdański

\section{POROZUMIENIE TRANSPACYFICZNE (TPP) BEZ STANÓW ZJEDNOCZONYCH}

\begin{abstract}
Streszczenie
W artykule podjęto próbę przedstawienia zmian zachodzących w Porozumieniu Transpacyficznym (The Trans-Pacific Partnership - TPP) w kontekście wycofania się Stanów Zjednoczonych z członkostwa w tym ugrupowaniu oraz ukazania alternatywnego wyjścia, jakim ma być powołanie TPP-11. Jest to problem ważny, ponieważ TPP miało integrować gospodarki 12 państw regionu Azji-Pacyfiku, który odgrywa kluczową rolę w gospodarce światowej. Jednocześnie TPP może być wzorem dla innych ugrupowań ze względu na osiągniętą jakość wynegocjowanych klauzul. Badania przeprowadzono posługując się metodą opisową na podstawie analizy literatury przedmiotu oraz publikacji i dokumentów WTO, rządów krajów uczestniczących w negocjacjach TPP i TPP-11. Opracowanie jest przyczynkiem do dyskusji nad regionalizmem azjatyckim.
\end{abstract}

Słowa kluczowe: TPP, TPP-11, RCEP, regionalizm, mega-grupowanie, międzyregionalne porozumienia handlowe, Azja

\footnotetext{
*Adres e-mail: ekokz@ug.edu.pl.
} 


\section{Wprowadzenie}

Trwający impas wielostronnej liberalizacji w ramach negocjacji Rundy Dohijskiej (DDA) na forum WTO skutkuje podejmowaniem przez członków WTO działań liberalizacyjnych na płaszczyźnie dwustronnej lub regionalnej. Dotyczy to aktywności we wszystkich regionach świata i koresponduje ze szczególnym zakresem i intensywnością proliferacji preferencyjnych (regionalnych) porozumień handlowych (preferential trade agreements - PTA; regional trade ageements - RTA), jaki ma miejsce od początku lat 90. XX wieku (trzecia fala regionalizmu - Żołądkiewicz, 2012, s. 199-202), a zwłaszcza od powstania Światowej Organizacji Handlu (WTO) (Hoekman, Kostecki, 2011, s. 50).

Coraz częściej ma także miejsce wsparcie dla procesu wielostronnej liberalizacji przez tworzenie międzyregionalnych, mega-ugrupowań porozumień handlowych (cross-regional trade agreements - C-RTA) (Fiorentino, Crawford, Toqueboeuf, 2009, s. 40 i n.; Michalski, 2014, s. 11), przekształcanie funkcjonujących porozumień integracyjnych lub ich konsolidacja (Baldwin, Evenett, Low, 2009, s. 79-141; Baldwin, 2006, s. 1451-1518). Jest to praktyczna realizacja koncepcji procesu uwielostronniania (mulitilateralizacji) regionalizmu, a jej zwolennicy podkreślają korzyści ekonomiczne wynikające z eliminacji „nakładających się” reguł pochodzenia, co jest ważne z punktu widzenia globalnych łańcuchów dostaw, międzynarodowych sieci produkcyjnych, czy też niwelowania asymetrii w negocjacjach handlowych dużych i małych gospodarek (Żołądkiewicz, 2015, s. 96). Ważnym argumentem jest pogłębiona formuła liberalizacji w nowych porozumieniach obejmująca tzw. zagadnienia WTO-plus (okołohandlowe), takie jak usługi, inwestycje, prawa własności intelektualnej, prawa pracownicze, polityka konkurencji, ochrona środowiska itp. (Woolcook, 2003, s. 18-31).

Znaczącą rolę w tym względzie spełniają tworzone w ostatnich latach międzyregionalne porozumienia handlowe mające na celu kompleksową, pogłębioną liberalizację wymiany handlowej w regionie Azji i Pacyfiku. Należą do nich podpisane w 2016 roku Porozumienie Transpacyficzne oraz negocjowane porozumienie RCEP'.

${ }^{1}$ The Regional Comprehensive Economic Partnership - Wszechstronne Regionalne Partnerstwo Ekonomiczne. 
Objęcie urzędu Prezydenta Stanów Zjednoczonych przez Donalda Trumpa zmieniło wiele założeń i oczekiwań w tym obszarze i oznacza konieczność weryfikacji i modyfikacji dotychczasowych ocen i przewidywań odnośnie do spodziewanych korzyści tych preferencyjnych porozumień handlowych. Jest to problem ważny, ponieważ TPP miało integrować gospodarki 12 państw regionu Azji-Pacyfiku, który odgrywa wiodącą rolę w gospodarce światowej ${ }^{2}$. Jednocześnie fakt ten był jednym z czynników intensyfikujących negocjacje innego mega-ugrupowania w tym regionie, porozumienia RCEP, które ma zintegrować gospodarki 16 krajów: 10 państw należących do ugrupowania ASEAN oraz Australię, Chiny, Indie, Japonię, Koreę Płd. i Nową Zelandię (6 państw) (Żołądkiewicz, 2016).

Celem niniejszego opracowania jest próba przybliżenia zmian zachodzących w Porozumieniu Transpacyficznym (TPP) w kontekście wycofania się Stanów Zjednoczonych z członkostwa $\mathrm{w}$ tym ugrupowaniu oraz przedstawienie alternatywnego wyjścia, jakim ma być powołanie TPP-11. Badania przeprowadzono posługując się metodą opisową na podstawie analizy literatury przedmiotu oraz publikacji i dokumentów WTO, rządów krajów uczestniczących w negocjacjach TPP i TPP-11.

\section{Wyjście Stanów Zjednoczonych z TPP}

W pierwszym dniu urzędowania (23 stycznia 2017 r.) Prezydent Donald Trump ogłosił wycofanie Stanów Zjednoczonych z Porozumienia Transpacyficznego z dniem 30 stycznia 2017 roku ,jako część działań mających chronić amerykańskich robotników" (Trump...). Oznaczało to, że po trwających ponad 10 lat rozmowach i negocjacjach, zakończonych ustaleniem tekstu Umowy TPP (TPPA $\left.{ }^{3}\right) 6$ października 2015 roku w Atlancie (USA) i podpisaniem 4 lutego 2016 roku w Auckland (Nowa Zelandia) przez ministrów handlu 12 krajów członkowskich umowy o powołaniu TPP, porozumienie - w swoim obecnym kształcie - nie może wejść w życie. Z zapisu w rozdziale 30 (artykuł 30.5.1) wynika, że Umowa może obowiązywać, gdy uzyska ratyfikacje przynajmniej sześciu krajów założycielskich TPP (w 2013 r.), na które łącznie przypada co najmniej 85\% PKB wszystkich sygnatariuszy (Report. Proposed Trans-Pacific Partnership..., 2017, s. 5). Tym samym obowiązywanie

\footnotetext{
2 Analiza genezy i postanowień TPP zob. w: Żołądkiewicz (2015), s. 93-110.

3 Trans-Pacific Partnership Agreement - Umowa Porozumienia Transpacyficznego.
} 
Umowy TPP wymagało ratyfikacji dwóch największych krajów członkowskich Stanów Zjednoczonych i Japonii, na które przypadało w powstającym ugrupowaniu 56\% wymiany handlowej i 80\% PKB (w 2014 r.). Prezydent Barack Obama próbował uzyskać aprobatę Kongresu USA podczas ostatnich dni swojej kadencji (koniec 2016 r.), ale po wyborze Donalda Trumpa zrezygnował z dalszych działań. Natomiast izba niższa parlamentu Japonii ratyfikowała umowę już na początku listopada 2016 roku (Helbe, 2017, s. 1, 16). Umowę ratyfikowała również Kanada (IP Negotiations Monitor, 2017, s. 12). TPP była też w trakcie ratyfikacji w kilku innych krajach (m. in. w Australii, Nowej Zelandii), ale ostateczne decyzje dotyczące TPP zostały odroczone.

Wycofanie się Stanów Zjednoczonych z członkostwa TPP zostało odebrane przez pozostałych sygnatariuszy jednoznacznie negatywnie. Stany Zjednoczone odgrywały w negocjacjach umowy TPP wiodącą rolę, były motorem tych negocjacji i wykazywały olbrzymią determinację-odnośnie do ich pozytywnego zakończenia. Te negocjacje były wyrazem reorientacji polityki amerykańskiej w kierunku Azji, która od wielu lat jest jednym z centrów gospodarki światowej, a gdzie USA traci swoją pozycję w imporcie tych krajów. Import krajów TPP ze Stanów Zjednoczonych spadł z ponad 40\% pod koniec lat 90 . XX wieku do poniżej 30\% w 2014 roku (Helbe, 2017, s. 6-7).

Zmiana stanowiska strony amerykańskiej była dla innych członków niezrozumiała, gdyż osiągnięte porozumienie wymagało trudnych, wszechstronnych negocjacji, szczególnie w kontekście zasady prowadzonych negocjacji umowy TPP, że ustalone wyniki rokowań staną się jednolitym zobowiązaniem (single undertaking - Hoekman, Kostecki, 2011, s. 161), mającym zastosowanie wobec wszystkich i dotyczącym wszystkich aspektów stosunków handlowych i zagadnień związanych $\mathrm{z}$ handlem. Chodziło o to, żeby wszyscy partnerzy porozumienia byli w stanie zaakceptować i realizować tę zasadę. Stąd negocjacje wymagały od krajów uczestniczących negocjowania bardzo wielu tematów i uzyskania w tym względzie zgody wszystkich partnerów.

Akceptacji TPP przez nową administrację Stany Zjednoczone powinien też sprzyjać fakt, że ugrupowanie oparto na koncepcji zapewniającej stałe dostosowywanie się do aktualnych realiów gospodarczych (living agreement). Oznacza to, że umowa miała być na bieżąco monitorowana, a adaptacja jej klauzul wymagała renegocjowania. Przyczyn tego należy upatrywać w zróżnicowaniu interesów krajów 
uczestniczących w porozumieniu, które integruje kraje bogate i biedne. Jednocześnie ugrupowanie miało umożliwić tym krajom dostęp do znaczących i wyłącznych korzyści związanych z oczekiwanymi efektami tworzonej strefy wolnego handlu. Stała aktualizacja umowy, celem jej dostosowania, spełniać więc miała ważną rolę, biorąc pod uwagę zróżnicowany potencjał gospodarczy krajów powołujących porozumienie TPP.

Ponadto, badania przeprowadzone w 2016 roku przez Petriego, Plummera i Zhaia $(2011,2016)$ wskazywały, że Stany Zjednoczone miały być największym beneficjentem porozumienia. Pełna implementacja TPP miała bowiem spowodować wzrost amerykańskiego PKB o 131 mld USD (0,5\%), wzrost eksportu o 357 mld USD $(9,1 \%)$ i wzrost napływu inwestycji bezpośrednich (BIZ) o 128 mld USD (o 1,9\%) w stosunku do danych szacunkowych prognozowanych dla 2030 roku. Kolejnym największym beneficjentem miała być Japonia, osiągając wzrost PKB o 125 mld USD (2,5\%), wzrost eksportu o 276 mld USD (23,2\%) i wzrost napływu BIZ o 92 mld USD (o 29,8\%). Znaczące korzyści miały także uzyskać gospodarki krajów słabszych ekonomicznie: Malezji - wzrost PKB o 52 mld USD (7,6\%), eksportu o 99 mld USD (20,1\%) i napływu BIZ o 48 mld USD (o 17,2\%) oraz Wietnamu - wzrost PKB o 41 mld USD (o 8,1\%), eksportu o 107 mld USD (30,1\%) i napływu BIZ o 92 mld USD (o 29,8\%). Badania pokazują też duże korzyści dla innych członków. Szacowano również możliwy wzrost płac w USA, brak zmian w wielkości zatrudnienia, ale przy potencjalnych niewielkich „roszadach” pracowników pomiędzy firmami. Te same badania wskazują na potencjalny wpływ integracji TPP na wzrost PKB wszystkich krajów członkowskich do 2030 roku na poziomie 465 mld USD (o 1,1\%), wzrost eksportu o 1025 mld USD (11,5\%) i napływu BIZ o 446 mld USD (3,5\%) (Petri, Plummer, 2016, tab. 3, 4).

\section{Negocjacje TPP}

Porozumienie o Partnerstwie Transpacyficznym miało w założeniach być ugrupowaniem „o wysokiej jakości, spełniającym standardy XXI wieku”. Można więc zapytać, czy po latach intensywnych negocjacji i wycofaniu się Stanów Zjednoczonych z członkostwa, idea powołania tego ambitnego, wyznaczającego nowe granice w kwestii głębokości i wszechstronności zakresu integracji mega-porozumienia integracyjnego, pozostanie aktualna. 
Porozumienie Transpacyficzne miało być forum pogłębionej integracji $12 \mathrm{kra}-$ jów w regionie Azji-Pacyfiku. W negocjacjach wzięło udział 12 krajów z czterech różnych regionów Azji-Pacyfiku: Stany Zjednoczone, Kanada i Meksyk (Ameryka Płn.), Australia, Nowa Zelandia (Oceania), Sułtanat Brunei, Malezja, Singapur, Wietnam, Japonia (Azja Wschodnia) i Chile, Peru (Ameryka Łacińska). Status „krajów założycielskich” należy do czterech krajów - Sułtanatu Brunei, Chile, Nowej Zelandii i Singapuru, które w 2006 roku powołały Umowę o Strategicznym Transpacyficznym Partnerstwie Ekonomicznym (TPSEP) ${ }^{4}$. W grudniu 2009 roku chęć przystąpienia do ugrupowania wyraziły Stany Zjednoczone (Trade Policy Review, 2010) $)^{5}$, a w marcu 2010 roku formalne negocjacje rozpoczęło już osiem krajów (Brunei, Chile, Nowa Zelandia, Singapur, Stany Zjednoczone, Australia, Peru i Wietnam). W dalszej kolejności do negocjacji przystąpiły: Malezja w 2010 roku, Meksyk i Kanada w 2012 roku i Japonia w 2013 roku. Ogółem TPP negocjowało 12 krajów Azji-Pacyfiku, na które przypada ok. 819 mln konsumentów (11,3\% ludności świata), 25,9\% handlu światowego i PKB na poziomie 27 trylionów USD (37,4\% światowego PKB) (dane za 2015 r. - Australian Government...). Negocjacje zostały zakończone w październiku 2015 roku, po odbyciu 19 rund negocjacyjnych ${ }^{6}$.

Pomimo rosnącej liczby krajów negocjujących TPP i różnic w poziomie ich rozwoju gospodarczego, spodziewane korzyści z członkostwa zdecydowały o dużym zaangażowaniu poszczególnych krajów w negocjacjach i zdolności do osiągania kompromisów, nawet w przypadku tematów „wrażliwych”. Świadczyło to o tym, że negocjacje prowadzone były przez kraje- jak to określił Helble (2017, s. 4) - będące „koalicją chętnych” (coalition of the willing) czy - według Elms (Lim, Elms, Low, 2012, s. 4) - „podzielające te same wartości i normy” (like-minded). Ostatecznie tekst Umowy TPP zawiera 30 rozdziałów (chapters) z aneksami i harmonogramami liberalizacji. Ustalenia dotyczą m.in. dostępu do rynku towarów i usług, reguł pochodzenia, biznesu elektronicznego, barier technicznych w handlu,

${ }^{4}$ The Trans-Pacific Strategic Economic Partnership - Strategiczne Transpacyficzne Partnerstwo Ekonomiczne.

${ }^{5}$ Uznaje się też, że koncepcja powstania TPP krystalizowała się na forum APEC już w latach 90. XX wieku, gdy Australia, Chile, Nowa Zelandia, Singapur i Stany Zjednoczone (P5) rozpoczęły dyskusję nad utworzeniem nowego typu ugrupowania.

${ }^{6}$ Dodatkowo odbywało się wiele nieformalnych spotkań na szczeblu przedstawicieli rządów podczas szczytów APEC czy spotkań G20. 
środków sanitarnych i fitosanitarnych, inwestycji, praw własności intelektualnej, polityki konkurencyjności, przedsiębiorstw państwowych, zakupów rządowych, kwestii pracowniczych, ochrony środowiska ${ }^{7}$. Ten wszechstronny zakres tematów integracyjnych, znacząco pogłębiona kooperacja i integracja krajów członkowskich reprezentujących szeroki zasięg geograficzny, sygnalizuje cechy charakterystyczne ugrupowań „o wysokiej jakości, XXI wieku”.

Stąd też duże zaangażowanie poszczególnych krajów w negocjacjach TPP, co miało się przełożyć na odpowiednie rezultaty z punktu widzenia ich gospodarek (zwłaszcza firm), w tym szczególna rola Stanów Zjednoczonych. Na kraje negocjujące TPP w 2015 roku przypadało 45\% amerykańskiego eksportu towarowego ogółem. W przypadku Australii udział ten stanowił 32\% eksportu towarowego ogółem, Japonii - 33\%, Nowej Zelandii - 43\%, Singapuru - 30\%, Brunei - 52\%, Kanady $82 \%$, Meksyku - 86\%, Peru - 31\%, Chile - 31\%, Malezji - $41 \%$ i Wietnamu - 39\%. Spośród wymienionych krajów najwyższy udział eksportu do USA w eksporcie ogółem do krajów TPP występował w eksporcie Meksyku - 81\%, Kanady - 77\%, Japonii - 20\%, Wietnamu - 19\%, Peru - 15\%, Chile - 13\% i Nowej Zelandii - $12 \%$. W pozostałych krajach udział ten był niższy, w Australii - 5\%, Singapurze - 6\%, Malezji 9\%, Brunei - 0,3\%. Z kolei udział tych krajów we wzajemnej wymianie handlowej, z wyłączeniem USA, jest relatywnie mniejszy (Jetro Global Trade..., s. 10).

\section{Scenariusze TPP bez USA}

Wycofanie Stanów Zjednoczonych z udziału w Porozumieniu Transpacyficznym spowodowało z jednej strony duże niezadowolenie krajów partnerskich, z drugiej - ich zdecydowaną reakcję. Oznaczało ono bowiem całkowitą zmianę sytuacji w odniesieniu do osiągniętych w negocjacjach rezultatów.

W tym kontekście można pokusić się o rozważenie czterech scenariuszy dla TPP (Elms, 2017b):

${ }^{7}$ Pełny tekst postanowień TPP można znaleźć na oficjalnych stronach internetowych ministerstw handlu poszczególnych krajów, np. http://dfat.gov.au/trade/agreements/tpp/official (2.05.2017).

${ }^{8}$ W swojej koncepcji takie ugrupowanie ma się różnić od porozumień określanych jako „ugrupowania XX wieku, które koncentrowały się głównie na usuwaniu barier celnych (często wyłączając nawet np. produkty rolne)". Lim, Elms, Low (2012), s. 3-17. 
1. 11 partnerów rezygnuje z TPP. Oznaczałoby to jednak, że jeden kraj może determinować rozwiązania w innych krajach, szczególnie w kontekście innowacyjnych rozwiązań integracyjnych, jakie zawiera wynegocjowane porozumienie.

2. Umowa pozostaje „w zamrażarce” i być może uda się do niej powrócić w połowie trwania kadencji prezydenta USA w 2018 roku. Argumentem przeciwko temu rozwiązaniu było ryzyko, że entuzjastycznie nastawiony do TPP biznes przestanie się w przyszłości interesować negocjacjami integracyjnymi, a obecnie uzyskane koncesje staną się nieaktualne.

3. Wykorzystanie niektórych części umowy w innych negocjacjach. Jest to koncepcja niewykonalna, ponieważ klauzule TPP są integralnie ze sobą powiązane, a ich usunięcie zniszczy tę cechę. Bezpośrednia transpozycja tych klauzul do innego ugrupowania czy porozumienia wielostronnego byłaby raczej niemożliwa.

4. Utworzenie porozumienia z udziałem 11 pozostałych krajów (TPP-11) po wprowadzeniu pewnych poprawek do tekstu umowy.

Antycypując decyzję prezydenta Trumpa, wygłoszoną 23 stycznia 2017 roku, już 14 stycznia premier Australii ogłosił, że „Australia i Japonia będą działać na rzecz szybkiego wejścia w życie TPP oraz zakończenia negocjacji RCEP” (Malcolm Turnbull...). Ponadto, podczas Światowego Forum Ekonomicznego w Davos (1720 stycznia) odbyło się spotkanie ministrów handlu Australii, Japonii, Kanady, Meksyku, Singapuru, Nowej Zelandii i Malezji poświęcone alternatywnym rozwiązaniom dla TPP. Wszyscy uczestnicy jednoznacznie potwierdzili wolę powołania TPP, wskazując na wiele korzyści z tego wynikających (Ciobo, 2017). Chodzi tutaj o poprawę warunków wzajemnego handlu i inwestycji w regionie, co ma się przełożyć na odpowiednie rezultaty z punktu widzenia stowarzyszonych gospodarek (zwłaszcza firm), a także o inne ustalenia (m.in. prawa pracownicze, ochrona środowiska, prawa własności intelektualnej).

Ostatecznie, w świetle decyzji USA, reprezentanci z 11 pozostałych krajów na spotkaniu w marcu 2017 roku w Chile uzgodnili konieczność prowadzenia konsultacji mających na celu powołanie TPP-11. Kolejne spotkanie ministrów handlu ma się odbyć przy okazji konferencji APEC w Wietnamie w dniach 20-21 maja 2017 roku. Podkreślając znaczenie ekonomiczne i strategiczne ugrupowania, ministrowie 
zasygnalizowali, że porozumienie powinno stać się kluczowym przykładem stosowania wysokich standardów i zasad w dalszej integracji regionu Azji-Pacyfiku.

\section{Podsumowanie}

TPP miało być nowoczesnym, o szerokim zakresie liberalizacyjnym, wysokiej jakości i wzajemnie korzystnym mega-ugrupowaniem integracyjnym. Jego powołanie miało stymulować handel i inwestycje pomiędzy krajami członkowskimi. Natomiast czy TPP bez udziału Stanów Zjednoczonych, jako TPP-11, może przynieść podobne spodziewane korzyści?

Istnieją obawy, że bez Stanów Zjednoczonych regulacyjny impuls TPP może osłabnąć, a niektóre wynegocjowane klauzule mogą zostać przez członków TPP-11 wycofane, ponieważ miały na celu uzyskanie koncesji od USA. Stąd ostateczne korzyści z ugrupowania dla jej członków będą w dużej mierze zależne od tego, na ile uda się utrzymać wynegocjowane w TPP postanowienia (Helbe, 2017, s. 18). Z drugiej strony ocenia się, że firmy krajów członkowskich i tak mają relatywnie łatwy dostęp do rynku amerykańskiego, więc nawet bez członkostwa USA dalsze relacje biznesowe nie powinny stanowić problemu (o ile nie nastąpią zmiany w ustawodawstwie USA) (Elms, 2017a).

Jednocześnie TPP-11 powinno realizować, choć w ograniczonym zakresie - ze względu na uczestnictwo relatywnie małej grupy państw - koncepcję multilateralizacji regionalizmu poprzez harmonizację reguł pochodzenia. Ważnym argumentem na rzecz utworzenia nowego ugrupowania jest także wysoka jakość wynegocjowanych rozdziałów i klauzul w TPP, które mogą stanowić wzór dla innych negocjowanych bloków handlowych. Helble stwierdza, że TPP zarówno pod względem prowadzenia negocjacji, jak i zawartości pewnych klauzul może być nawet inspiracją dla negocjacji na poziomie wielostronnym. Ogólnie ocenia się, że TPP-11 przyniesie konkretne i mierzalne korzyści dla firm, dzięki zobowiązaniom, jakie daje członkostwo w ugrupowaniu oraz zmniejszeniu ryzyka związanego z działaniami zniekształcającymi warunki handlu i inwestycji.

Warunkiem niezbędnym do powołania TPP-11 będzie konieczność modyfikacji zapisu w rozdziale 30 (artykuł 30.5.1) w celu dostosowania możliwości wejścia w życie Umowy TPP w nowych realiach odnośnie do mniejszych potencjałów gospodarczych krajów członkowskich (bez USA). Wskazuje się też na możliwość 
zakończenia prac nad tekstem i harmonogramami liberalizacyjnymi do kwietnia 2018 roku.

\section{Literatura}

Australian Government. Department of Foreign Affairs and Trade. Pobrano z: http://dfat. gov.au/trade/agreements/tpp/official (2.05.2017).

Baldwin, R. (2006). Multilateralizing Regionalism: Spaghetti Bowls as building Blocs on the Path to Global Free Trade. NBER Working Paper, 12545, September.

Baldwin, R., Evenett, S., Low, P. (2009). Beyond Tariffs: Multilateralizing Non-Tariff RTA Commitments. W: R. Baldwin, P. Low (red.), Multilateralizing Regionalism: Challenges for the Global Trading System. Cambridge: Cambridge University Press.

Ciobo, S. (2017). Trans-Pacific Partnership. Media Release, 22 January.

Elms, D. (2017a). Moving Ahead with the TPP11. Singapore: Asian Trade Centre.

Elms, D. (2017b). TPP: Not Dead Yet. ATC Singapore, 9 March.

Fiorentino, R.V., Crawford, J-A., Toqueboeuf, C. (2009). The Landscape of Regional Trade Agreements and WTO Surveillance. W: R. Baldwin, P. Low (red.), Multilateralizing Regionalism. Challenges for the Global Trading System. Cambridge: Cambridge University Press

Helble, M. (2017). Salvaging the Trans-Pacific Partnership: Building Blocks for Regional and Multilateral Trade Opening?. ADBI Working Paper, 695, March.

Hoekman, B., Kostecki, M.M. (2011). Ekonomia światowego systemu handlu. Wrocław: Wydawnictwo Uniwersytetu Ekonomicznego we Wrocławiu.

IP Negotiations Monitor (2017). No. 21, January-March.

Jetro Global Trade and Investment Report 2016. JETRO, Overseas Research Department. Pobrano z: https://www.jetro.go.jp/ext images.

Lim, C.L., Elms, D.K., Low, P. (2012). What is "High-quality, Twenty-first Century" Anyway? W: C.L. Lim, D.K. Elms, P. Low (red.), The Trans-Pacific Partnership. A Quest for a Twenty-first-Century Trade Agreement. Cambridge: Cambridge University Press.

Malcolm Turnbull, Shinzo Abe Agree to Push for TPP Despite Trump Scepticism. Pobrano z: www.abcnews.com.au (3.05.2017).

Michalski, B. (2014). Międzyregionalne porozumienia handlowe. Transpacyficzny regionalizm jako alternatywa dla ,wolnego" handlu? Warszawa: Difin.

Petri, P.A., Plummer, M.G. (2016). The Economic Effects of the Trans-Pacific Partnership: New Estimates. PIIE Working Paper, 16-2. 
Petri, P.A., Plummer, M.G., Zhai, F. (2011). The Trans-Pacific Partnership and Asia-Pacific Integration: A Quantitative Assessment. East-West Center Working Paper, 119.

Report. Proposed Trans-Pacific Partnership (TPP) Agreement (2.12) (2017). Canberra: Department of the Senate, Parliament of Australia, Commonwealth of Australia.

Trump. Make America Great Again. Pobrano z: https;//assets.donaldjtrump.com/contract for_the_voter.pdf (1.05.2017).

Woolcock, S. (2003). A Framework for Assessing Regional Trade Agreements: WTO-plus. W: G.P. Sampson, S. Woolcock (red.), Regionalism, Multilateralism, and Economic Integration. Tokyo-New York-Paris: United Nations University Press.

Żołądkiewicz, K. (2012). Fale regionalizmu. W: R. Orłowska, K. Żołądkiewicz (red.), Globalizacja i regionalizacja w gospodarce światowej. Warszawa: PWE.

Żołądkiewicz, K. (2015). Partnerstwo Transpacyficzne (TPP) jako nowe porozumienie integracyjne w regionie Azji-Pacyfiku. Studia i Prace WNEiZ, 41 (1).

Żołądkiewicz, K. (2016). Wszechstronne Regionalne Partnerstwo Ekonomiczne (RCEP) jako przykład nowego trendu w regionalizmie. Finanse, Rynki Finansowe, Ubezpieczenia, 3 (81).

\title{
THE TRANS-PACIFIC PARTNERSHIP (TPP) WITHOUT THE UNITED STATES
}

\begin{abstract}
The goal of this paper is to present changes in the Trans-Pacific Partnership (TPP) in the context of the decision of the United States to withdraw from the agreement, and to present an alternative solution in the form the TPP-11. It is an important issue because the TPP was aiming to unite 12 countries of Asia-Pacific region which plays a significant role in the world economy. Simultaneously, the TPP can serve as a model for other groupings in terms of quality of its provisions. The outcome of this paper was based on critical analysis of the literature of the subject and documents of the WTO and the TPP negotiations supplied by governments of countries participating in both the TPP and the TPP-11 negotiations. This paper is a part of the discussion on the trends in regionalism.
\end{abstract}

Keywords: TPP, TPP-11, RCEP, regionalism, mega-trade agreement, cross-regional trade agreements, Asia

JEL codes: F13, F15, F55 
